\title{
The Effects of Referential Questions in Pre-writing Activities on Students' In-class Participation and Written Production
}

\author{
Elif Kemaloglu Er ${ }^{1}$
}

\section{Type/Tür:}

Research/Araştırma

Received/Geliş Tarihi: June

15/ 15 Haziran 2020

Accepted/Kabul Tarihi:

August 4/ 4 Ağustos 2020

Page numbers/Sayfa No: 698 -

714

Corresponding

Author/İletişimden Sorumlu

Yazar:

ekemalogluer@atu.edu.tr

\section{$\checkmark$ iThenticate}

This paper was checked for plagiarism using iThenticate during the preview process and before publication. / $\mathrm{Bu}$ çalışma ön inceleme sürecinde ve yayımlanmadan önce iThenticate yazılımı ile taranmıştır.

Copyright $(92017$ by Cumhuriyet University, Faculty of Education. All rights reserved.

\begin{abstract}
Types of teacher questions play a crucial role in students' foreign language development. Among teacher questions, referential questions asked to enable students to provide data not known by the teacher, express their views and exchange personal information and ideas are particularly important as they can affect students' inclass participation and language production. Writing is a complex production process and pre-writing activities are defined to be an essential step to improve writing performance. In these activities, referential questions may act as effective means to encourage students' in-class participation and written production. However, referential questions in pre-writing activities in English language teaching have not yet been investigated. This study aims to investigate the forms and functions of referential questions in prewriting activities and teacher and student views about their effects on students' in-class participation and written production. 63 English language learners and their writing instructor participated in the study. The data were collected by classroom observations and teacher and student interviews and analysed via conversation and thematic analysis. The findings showed that referential questions were used in a variety of forms and had productive, communicative, pedagogical and motivational functions. The teacher and students emphasized that referential questions had substantial impacts on inclass participation and written production. They were reported to attract students' attention, enhance their motivation to speak, promote oral participation and lead to complex responses. Also, referential questions were stated to provide guidance for the production of written outputs generated with the help of collaboratively constructed content in the classroom.
\end{abstract}

Keywords: English language teaching, English as a foreign language, writing, referential questions, pre-writing activities

\footnotetext{
Suggested APA Citation/Önerilen APA Atıf Biçimi:

Kemaloglu-Er, E. (2021). The effects of referential questions in pre-writing activities on students' in-class participation and written production. Cumhuriyet International Journal of Education, 10(2), 698714. http://dx.doi.org/10.30703/cije.753039
}

\footnotetext{
1 Dr. Öğretim Üyesi, Adana Alparslan Türkeş Bilim ve Teknoloji Üniversitesi, İnsan ve Toplum Bilimleri Fakültesi, İngilizce Mütercim ve Tercümanlık Bölümü, Adana/Türkiye Assist. Prof. Dr., Adana Alparslan Türkeş Science and Technology University, Faculty of Humanities and Social Sciences, Department of Translation and Interpreting, Adana/Turkey e-mail: ekemalogluer@atu.edu.tr ORCID ID: orcid.org/0000-0003-1238-1018
} 


\title{
Yazma Öncesi Faaliyetlerdeki Göndergesel Soruların Öğrencilerin Sınıf içi Katılımına ve Yazılı Üretimine Olan Etkileri
}

\begin{abstract}
Öz
Öğretmenlerin soru türleri öğrencilerin yabancı dil gelişiminde çok önemli bir rol oynamaktadır. Öğretmen soruları arasında öğrencilerin öğretmen tarafından bilinmeyen veriler sağlamaları, görüşlerini ifade etmeleri ve kişisel bilgi ve düşünce alışverişinde bulunmalarına olanak tanımak için sorulan göndergesel sorular özellikle önemlidir zira bu sorular öğrencilerin sınıf içi katılımını ve dil üretimini etkileyebilmektedir. Yazma karmaşık bir üretim sürecidir ve yazma öncesi faaliyetler yazı performansını geliştirmek için gerekli bir adım olarak tanımlanmaktadır. Bu faaliyetlerde göndergesel sorular öğrencilerin sınıf içi katılımını ve dil üretimini teşvik etmede etkin araçlar olarak işlev gösterebilir. Ancak İngilizce dili öğretiminde yazma öncesi faaliyetlerde yer alan göndergesel sorular henüz araştırılmamıştır. Bu çalışma yazma öncesi faaliyetlerdeki göndergesel soruların biçim ve işlevlerini ve bu soruların öğrencilerin sınıf içi katılım ve yazılı üretimine olan etkileri hakkındaki öğretmen ve öğrenci görüşlerini araştırmayı amaçlamaktadır. Çalışmaya 63 İngilizce dili öğrenicisi ve kendilerine yazma eğitimi veren öğretim görevlisi katılmıştır. Veriler sınıf gözlemleri ve öğretmen ve öğrenci mülakatlarıyla toplanmış ve konuşma çözümlemesi ve tematik analiz yoluyla incelenmiştir. Sonuçlar göndergesel soruların çeşitli biçimlerde kullanıldıklarını ve üretimsel, iletişimsel, pedagojik ve motivasyonel işlevlere sahip olduklarını ortaya koymuştur. Öğretmen ve öğrenciler göndergesel soruların öğrencilerin sınıf içi katılımına ve yazılı üretimine kayda değer etkileri olduğunu vurgulamışlardır. Göndergesel soruların öğrencilerin dikkatini çektiği, konuşma motivasyonlarını arttırdığı, sözlü katılımı teşvik ettiği ve karmaşık yanıtlara yol açtığı beyan edilmiştir. Ayrıca göndergesel soruların sınıf içinde kollektif bir biçimde oluşturulan içerik yardımıyla üretilen yazılı ürünlerin oluşturulmasında yol gösterici olduğu belirtilmiştir.
\end{abstract}

Anahtar Kelimeler: İngilizce dil öğretimi, yabancı dil olarak İngilizce, yazma, göndergesel sorular, yazma öncesi faaliyetleri

\section{Introduction}

Writing in L2 classes is a complex process where the thoughts of the learners are made to be visible and concrete on paper in the language they are learning. Writing stimulates thinking and learning of both the author and readers and presents a framework where the written thoughts become available for reflection (Matsuda, 2003). Furthermore, writing in L2 is very significant in the way that it acts as a channel to L2 learning and improvement by making learners express their ideas and emotions in a meaningful and purposeful way (Eisterhold, 1990; Hyland, 2014). By writing in L2, learners can experiment with the linguistic system of the target language and test and enhance their knowledge of grammar, vocabulary and stylistics (Grabe \& Kaplan, 1996).

Despite its significant role and importance, most second language learners have difficulty when they want to write in L2. The problems may be caused by inadequate preparation for the writing tasks (Hyland, 2014). Learners may be unknowledgeable about the text type and structure and have difficulty in finding related ideas, therefore, their content might be poor and ineffective (Richards \& Renandya, 2002). The situation can even be worse if learners in their first language contexts do not have adequate background experience regarding writing practice which can negatively affect their writing practices in L2 contexts (Altinmakas \& Bayyurt, 2018). The complexity of the 
writing task can be pedagogically managed if writing is accepted to be a process rather than a product and teacher guidance addressing the needs of learners is provided to the students in this entire process (Hairston, 1992; Peregoy \& Boyle, 2017). The processbased approach allows learners to deal with the writing task effectively by going through different stages which involve pre-writing as the first stage, followed by writing through drafting, revising, editing and publishing (Johnson, 2008; Peregoy \& Boyle, 2017).

Pre-writing is defined to be a very significant step in improving writing performance, and it is emphasized the more time for the pre-writing stage is devoted, the better the quality of the writing performance gets (Graham \& Perin, 2007; Holmes, 2003; Lally, 2000; Shin, 2008; Tompkins, 2001; Zheng \& Dai, 2012). Lally (2000) calls pre-writing the idea generation stage and highlights the importance of pre-writing activities as they aid students discuss a topic, develop ideas, and arrange the content and the outline in order to develop the quality of their writing. Zheng \& Dai (2012) point out the catalyst role of pre-writing in active participation of learners in several processes such as thinking, talking, group interaction, and skeletal writing. Prewriting activities can be done in the form of teacher-led whole class discussions or group work, which can help students engage in meaningful conversations on the issue and generate appropriate ideas and context-specific outlines (Grabe \& Kaplan, 1996). The studies that examined the effects of pre-writing discussion on writing outcomes have shown that after discussing the writing topic and writing process, students write qualitatively better (Bossio, 1993; Kennedy, 1983; Lally, 2000; Lay, 1982; Meyer, 1980; Shi, 1998; Sweigart, 1991; Xianwei, 2009) and better understand the complexity of topics (Sweigart, 1991).

Teacher questions in pre-writing activities can also serve as a purposeful tool to better reflect on the issue and lay the grounds for effective writing since outputs from students are often triggered with the aid of questions (Brown, 2007). When teacher questions are analysed, there are mainly two types of questions defined and categorized in literature and these are display and referential questions. Display questions are the ones whose answers are already known by the teacher and which the students are asked in order to have them present their knowledge or check their understanding (Brock, 1986; Long \& Sato, 1983; Thompson, 1991; Thornbury, 1996). On the other hand, answers of referential questions are not known by the teacher as they are based on the knowledge of the addressee (Long \& Sato, 1983). Referential questions are asked to learners to enable them to provide data unknown to the teacher, express their views and exchange personal information or opinions (Brock, 1986; Long \& Sato, 1983; Thompson, 1991; Thornbury, 1996). As referential questions seek new information, they have no one particular answer, thus they are asked to activate genuine communication and tend to lead to 'natural' responses (Nunan \& Lamb, 1996). Morell (2007) indicates the teacher's use of referential questions in language classrooms can increase the opportunity for negotiation of meaning between teacher and learners. Nunan (1989) states learners make a greater effort and more in-depth processing in replying referential questions compared to display questions. According to Walsh and $\mathrm{Li}$ (2013), referential questions are more likely to promote debate and discussion, enhance learners' involvement and encourage them to use more complex language as they are meaning-oriented. 
Referential questions are used in the form of yes-no questions or wh- questions and have the functions of seeking information not known by the addressor, enhancing communication and increasing productivity in the L2 classroom (Brock, 1986; Kocer, 2003; Long \& Sato, 1983; Thompson, 1991; Thornbury, 1996; Ozcan, 2010). The constructive role of referential questions in language development is highlighted with these functions since they can make the students more productive and communicative in the process with the realistic situations they create enabling students to express personal information and ideas (Brock, 1986; Long \& Sato, 1983; Thompson, 1991; Thornbury, 1996). Also referential questions are stated to prompt more participation in the classroom since they are not bound with limited answers, increase students' selfconfidence and motivation and have the potential to lead to a positive context where the students can freely express themselves and their own viewpoints (Kocer, 2003; Ozcan, 2010).

Studies on referential questions display their potential to influence the extent and complexity of student output. Brock (1986) analyzed the the length and complexity of students' responses given to referential questions and it was found that through referential questions, students made longer sentences and used more logical connectors in their speech. The studies that compared the answers given to referential questions to those provided for display questions also confirmed referential questions lead to longer and more complex outcomes compared to display questions (Bozorgian \& Fallah, 2017; Ernst, 1994; Lindenmeyer, 1990; Qashoa, 2012; Ozcan, 2010; Yilmaz, 2016; Zohrabi, Yaghoubi-Notash \& Khiabani, 2012).

Apart from studies that compare display and referential questions in English classrooms, there are few studies on the views of students and teachers about the use of referential questions in such settings. In Khadraoui (2016), both students and teachers had positive attitudes towards the effect of referential questions on classroom interaction. The teachers reported referential questions enable students to practice language more, produce longer utterances and improve their critical thinking skills. The students stated referential questions aid them activate their thinking and reasoning and promote participation. In Farahiana and Rezaee (2012), according to teacher reports, referential questions were believed to create authentic conversations and help students use language in a fruitful manner. In Ozcan (2010), the students said since there is no certain answer to a referential question, this type of question gives them a chance to express their opinions, creates a variety, allows them produce more sentences with the language they are learning and helps them improve their speaking skills. However, some students were found to be hesitant in answering referential questions due to their lack of confidence. The teachers in Ozcan (2010) reported referential questions develop students' critical thinking skills, encourage participation and aid to create a lifelike atmosphere in the classroom since through them students can express and exchange their ideas. This research is centred on the synthesis of two subjects namely, referential questions and pre-writing activities. This is due to a commonality they share: Either of them has the potential to promote students' in-class participation and language production. To make English language teaching effective, there should be the use of not only receptive skills but also productive skills so that the language can be used holistically as in real life. Also to make both oral and written production efficient, meaningful and purposeful, teacher guidance is necessary. This 
brings us to the significance of the topic, which is referential questions asked by teachers in pre-writing activities, with the possibility to affect in-class participation and written production. Although either referential questions or pre-writing activities have attracted the attention of researchers as separate topics, there are no studies investigating them together in the field of English language teaching. This study aims to investigate the forms and functions of referential questions in pre-writing activities and teacher and student views about their effects on students' in-class participation and written production.

The study addresses the following questions:

1. What forms do the referential questions have in pre-writing activities?

2. What functions do the referential questions have in pre-writing activities?

3. What are the teacher's views about the effects of referential questions in prewriting activities on students' in-class participation?

4. What are the teacher's views about the effects of referential questions in prewriting activities on students' written production?

5. What are the students' views about the effects of referential questions in prewriting activities on their in-class participation?

6. What are the students' views about the effects of referential questions in prewriting activities on their written production?

\section{Setting}

\section{Method}

This qualitative case study was conducted in the pre-intermediate level English preparatory classes within the School of Foreign Languages of a Turkish state university in the spring semester of 2018. There are four courses in the program, namely Main Course, Reading, Writing and Listening and Speaking. The study was conducted in the Writing classes of the program where the students are guided about writing descriptive and narrative paragraphs, letters, stories and essays. The course time is devoted mostly to pre-writing activities where information about the writing type is given and preparation for writing is made by relevant teacher-led whole class discussions on the topic as well as exercises and mini-tasks via a writing-focused coursebook. The students are mostly asked to write their writings at home and submit them to their teacher, who often checks them outside the class and gives students written feedback on paper as well as oral feedback in the course hours. Thus the main components of the course are pre-writing activities and feedback on student writing.

\section{Participants}

63 English language learners and their writing instructor participated in the study. The students were members of three pre-intermediate level English preparatory classes. They were young adult male and female EFL learners between 18-24 years old. The teacher was a 41-year old female instructor. She graduated from a Faculty of Education in Turkey. Her major was English Language Teaching. She has 17 years' English language teaching experience and 15 years' writing instruction experience.

\section{Data Collection Procedures}

The data were collected via classroom observations, semi-structured interviews with the teacher and focus group interviews with the students. The teacher and students 
were informed about the study, the procedures and confidentiality and voluntarily participated in the research.

There were fifteen 45-minute classroom sessions observed and recorded, all devoted to pre-writing activities. In the pre-writing activities, teacher-led discussions were held on the writing topics the students were expected to write about, information about the type of writing was provided to the students, outlines for the relevant writings were made and sample writings were presented with exercises through a coursebook. In the pre-writing discussions the students' attention was attracted to the topic through personal questions, and they were encouraged to discuss the topic extensively and generate ideas. The writing types to be written were the first person story, third person story and for and against essay. The classes were observed by the researcher without any intervention. Field notes were taken during the observations. Semi-structured interviews with the teacher were arranged and conducted in the form of a two-step process performed after the pre-writing sessions as well as feedback sessions of three writing types. Firstly, after the pre-writing sessions of each writing type, namely first person story, third person story and for and against essay, the teacher was shown the transcripts of the lessons with the referential questions highlighted. For each writing type, the teacher was asked to analyse and comment on the effects of her referential questions on the students' in-class participation. Secondly, following the writing and evaluation processes of each writing type, she was provided with the transcripts again with the highlighted referential questions and there were also the students' writings in front of the teacher. This time the teacher was requested to analyse and comment on the effects of her referential questions in the pre-writing activities on the students' written production.

For focus group interviews with the students, the teacher was asked to choose 9 students from each class, displaying low, mediocre and high proficiency in writing according to their exam scores and the teacher's own evaluations. There were 3 students representing these 3 proficiency levels from 3 classes. The students were not told how they were assigned. 27 students in total were interviewed through the given technique. In each group there were 9 students. They were first informed about referential questions through a session where a general informative presentation was made. This was followed by detailed specifications where the students were shown example question-answer interactions from their pre-writing classroom recordings. Then each student was also provided with sample transcripts from their in-class prewriting activities involving story and essay writing and asked to analyse the teacher's referential questions and student responses given to them. The students also had their own writings with them. After this informative and reflective training, each group was interviewed about the effects of referential questions in pre-writing activities on their in-class participation and written production.

\section{Data Analysis}

The data were qualitatively analyzed by conversational analysis as well as thematic analysis. As stated by Sert and Seedhouse (2011), conversation analysis investigates various dynamics of classroom-talk-in-interaction and highlights the nature of language teaching and learning practices. Conversation analyses were made both at a micro and a macro level (Seedhouse, 2011) focusing on specific utterances, which is referential questions in our case as well as interactional patterns involving referential 
questions and the relevant responses given to them in whole class interaction. For the forms of referential questions asked by the teacher, the questions asked were analysed and categorized according to the way they were formulized. To analyse the functions of referential questions, each question and relevant student responses given to the question were analysed and the functions were defined through conversation analyses focusing on the intended purposes. Then the repetitive patterns were grouped, categorized and named under the given titles. To investigate the teacher's and students' views about the effects of referential questions in pre-writing activities on students' participation and written production, thematic analysis was used. In thematic analysis, the emerging patterns or themes are defined and categorized by moving back and forth within the data via multiple readings (Creswell, 2013). To this end, the interviews with the teacher and students were thematically analysed through iterative readings and in-depth analyses and the given effects were meticulously refined and defined.

\section{Forms of Referential Questions}

\section{Findings}

The analyses of the forms of referential questions involved data from two main lesson themes: writing a story and writing an essay. In this section, in order to make the findings about the forms of referential questions clear to the reader, first the general contents of the pre-writing lessons analysed in this study will be described according to the writing types, then the forms will be presented.

In the pre-writing sessions of story writing lessons, there were mainly two stages. In the first stage, the teacher aimed to get the students to make up a sample story through whole class participation with referential questions. The teacher first explained they were going to write a sample story collectively and started a sample paragraph beginning with a sample sentence like "While I was walking in the park...". She then wanted the students to make up a story by making their own sentences. Based on their answers, the teacher asked the students several referential questions to have them gradually and collectively build up their own collective story. In another example, the teacher made use of sounds to activate the imagination of the students and asked them questions to prompt creative responses for story building. In a sample session, for instance, she made the students close their eyes and while their eyes were closed, she made the sound of a snake by saying "ssss". She repeated this sound and asked the students to form a picture in their minds. Then she asked the students to open their eyes and asked referential questions to stimulate students' imagination and elicit information to add to the story. Then she asked the students to close their eyes again and made the sound of a horse by saying "dig1dik dig1dik" (Turkish equivalence of "clip clop", the galloping sound of a horse). Following this, she asked them to open their eyes and asked referential questions to make the students describe the pictures formed in their minds. As explained below, the questions asked by the teacher included $5 \mathrm{Ws}$ and $1 \mathrm{H}$ which were the questions to be answered in the beginning paragraph of the story: who, what, when, where, why and how. She also asked yes-no questions, this-or-that questions and intonation questions to elicit information as elaborated below. After this in-class pre-writing practice, in the second stage, the teacher moved on to the topic of story writing. She informed the students about story writing by making use of the students' answers to the questions asked in the teacher- 
led story building practices. Then she told students to open the story part in their coursebooks, read aloud the sample story and did the relevant exercises.

The second type of pre-writing activities focused on preparation to write a for and against essay about the advantages and disadvantages of a type of sport. In these lessons, the teacher first made a warm-up activity and asked different students several referential questions about their interests in sports. Then she made a brainstorming activity by asking a further referential question to the students to name different kinds of sports. Following this, she classified sports as individual and team sports with the students. Then she focused on a type of sport (e.g. swimming) from among the given items and with the help of further referential questions, she asked students to tell the advantages and drawbacks of the given sport and elaborate on them. Following this, the class started to do the pertinent unit within the book with a relevant sample essay and exercises.

In the pre-writing sessions, the types of referential questions categorized according to their forms were i) questions formed with question words (i.e. with $5 \mathrm{Ws}$ and $1 \mathrm{H}$ : who, what, when, where, why and how), ii) yes-no questions, iii) this-or-that questions, and iv) intonation questions. The first type of questions asked by the teacher in the pre-writing sessions involved questions formed with question words. They were formed with "who", "what", "when", "where", "why" and "how". The statements were either full statements or statements with only the question words. This type of referential questions in the story-focused lessons aimed for setting the scene of the story and telling the upcoming events together with the class via answers to these questions. Here are some examples from different lessons:

Who is the main character?

What happened?

When did you say goodbye?

Where were you sitting?

Why did he say that?

How was the weather?

Furthermore, questions with $5 \mathrm{Ws}$ and $1 \mathrm{H}$ asked by the teacher also targeted at eliciting information about students' interests and opinions about the given subject of the essay, which was sports. Below are some sample statements:

What sports do you do?

What are the advantages of swimming?

What do you think are the drawbacks of playing football?

The second type of question was the yes-no question. Yes-no questions were usually asked to show interest in the students' preferences in essay-oriented lessons or for clarification purposes in building a collective story in story-oriented lessons.

Do you do any sports?

Is the man tall?

Are the people happy?

Does the house have a garden?

The third type of question was the this-or-that question. These questions were asked to have the students make a choice between the given items.

Is this place a house or a flat?

Is the girl happy or sad?

Do you prefer team sports or individual sports? 
The fourth type of question was the intonation question which did not have the grammatical form of a question, but had an interrogative nature due to the rising intonation used. The teacher was seen to use intonation questions to have the students elicit more information to complete a story in the story-oriented sessions or clarify the content of students' responses in essay-oriented sessions. Sample referential questions asked in this form are as follows:

While I was walking in the park?

While you were walking in the park you saw two birds, then?

They were colourful?

You looked after them?

You are good at all these sports?

Thus, in the pre-writing sessions, there were a variety of referential questions asked by the teacher in different forms to generate student responses.

\section{Functions of Referential Questions}

The referential questions in the pre-writing activities had several functions categorized and identified as the i) productive, ii) communicative, ii) pedagogical, and iv) motivational functions following data analyses. Firstly, referential questions assumed productive functions in the way that they prompted students to generate responses revealing their own creativity and opinions as well as responses about their own lives and helped them produce spoken and written outcomes reflecting each person's ideas and imagination. Moreover, referential questions had communicative functions as the students communicated what is there in their real worlds outside the classroom through their answers. These types of questions were asked to show interest in the daily lives of the students, their preferences and abilities within a certain field, and their personal experiences as well as their feelings and reactions about these experiences. Also they had the purpose of learning about the opinions of students about a given subject. Thus they formed a highly communicative platform where the course content was related to the students' own lives in a context-sensitive manner. The pedagogical function of referential questions in the pre-writing activities was teaching the students how to write a story and a for against essay so they laid the grounds for the content to be used in the students' writings as well the outline. They also served as means to practise the grammar necessary for the type of writing such as the use of past continuous tense and past tense and the use of conjunctions like "when" and "while" in story writing. Lastly, the referential questions had motivational functions as the students were observed to eagerly participate in the lessons and motivatedly interact with each other while making collaborative suggestions and seemingly enjoying the lessons with responses of smiles and laughter.

\section{Teacher's Views about the Effects of Referential Questions in Pre-writing Activities on in-class Participation}

According to the teacher, the referential questions she asked in the pre-writing lessons helped the students participate in the lesson actively and efficiently. She reported a great majority of her referential questions in the pre-writing sessions were responded clearly, understandably and meaningfully. The teacher said in the pre-writing sessions dominated with the ask-and-answer processes of her referential questions, the atmosphere was lively and dynamic, different students were involved in the 
discussions and the sense of freedom the referential questions created made students participate in the lessons both individually and collaboratively. For example in the prewriting sessions of the for and against essay on sports, a multifarious and lively interaction was observed: The teacher asked the students if they did sports and asked further referential questions about whether they did the sport types she stated and if the students reported they were interested in some sport types, she asked how they performed the mentioned sport types and if not she even used this chance and asked which sports the students hoped to play. Then she focused on a sport type (e.g. football) and asked about the advantages and drawbacks of playing football. The teacher said the variety in her questions and her addressing to different students positively affected student participation. Additionally, it was mentioned that the questions asking for students' interests and opinions created opportunities for communication similar to that in real life. All these, according to the teacher, led to a positive interaction atmosphere in the class. As she pointed out, as a result of the referential questions in the pre-writing sessions, the students got acquainted with the topic, brainstormed on the content and became actively and motivatedly involved in the speaking production process and got ready for another production stage which would be in the form of real writing as the next step. It was also emphasized that there were a great variety of grammatical structures and vocabulary items in this intense form of communication so the teacher stated referential questions gave the students an opportunity to practice various forms and often build sophisticated outputs. As a result the teacher reports revealed referential questions positively influenced students' in-class participation as they drew students' attention to the lesson, created a lively classroom atmosphere and increased their motivation to speak, made them communicate personal facts and ideas and construct their own spoken outputs with relatively complex structures and the teacher believed all these paved the way for a sound writing process.

\section{Teacher's Views about the Effects of Referential Questions in Pre-writing Activities on sStudents' Written Production}

The teacher analysed both the referential questions in her pre-writing sessions and the writings that the students submitted after these sessions and said referential questions in pre-writing activities had positive impacts on students' written production. She pointed out she was mostly able to see the answers of her referential questions built in the $5 \mathrm{Ws}$ and $1 \mathrm{H}$ technique (i.e. the technique of asking who-what-where-when-why and how questions) in the stories the students wrote. The teacher stated the students were successful in setting the background scene with the answers to these questions in their stories and telling the event with the sections of introduction, development and conclusion. Another contribution of referential questions was said to be about the possible grammatical structures used in the story. The teacher said she believes her making incomplete sentences with "while" and "when" and asking the students to complete them had certain benefits in students' forming sentences with them and using the appropriate past tenses in accurate forms. Thus according to the teacher's reports, referential questions she asked in pre-writing lessons had an influence on not only the content of story writing but also the necessary forms within.

As for essay writing, the teacher reported that in the pre-writing lessons, she asked students several referential questions on the advantages of disadvantages of the 
given sport and elaborate on these benefits and drawbacks. She was then pleased to find well-written essays on the pros and cons of a sport type chosen by students. The teacher said her questions made the students get accustomed to the essay type, build a relevant outline in the form of introduction, advantage paragraph, disadvantage paragraph and conclusion, generate ideas and write the content meaningfully and purposefully with the necessary structures as a unity of clearly arranged paragraphs supported with sound justifications. The teacher said she believed her referential questions also increased the students' motivation to write since there were a great number of writing submissions, the content of most writings reflected a wellconstructed content and in the feedback sessions several students reported they liked the pre-writing sessions especially those focusing on story building where they closed their eyes and imagined and built up their own stories with teacher questions. She concluded asking referential questions stimulates students' creative thinking as well as critical thinking skills and she believes the students made use of these skills first through speaking and then writing on the topic with the help of referential questions which guided the entire process. Thus according to the teacher reports, the use of referential questions in pre-writing sessions were stated to provide guidance for written outcomes generated with the aid of content collaboratively constructed in the classroom.

\section{Students' Views about the Effects of Referential Questions in Pre-writing Activities on in-class Participation}

The students overall showed a positive attitude towards the use of referential questions in pre-writing activities and stated referential questions promote in-class participation since with the help them, they speak more in the lessons. As mentioned by most students, this is because this type of question has the power to make them express facts about their own lives and/or their own ideas about various aspects of life and this increases their enthusiasm to speak in the lessons. Some students also indicated such questions imply students' ideas matter in the lessons and they feel esteemed. Several students pointed out the lessons and the topics of the lessons become interesting by referential questions because when such questions are asked about the current topic of the lesson, they can become interested in it and personally relate to the content intended to be taught that day. Some said they may even be unknowledgeable about the topic and by talking about their own life, they can feel closer to it and understand it better when it is taught. On the other hand, a couple of students reported they don't feel comfortable when they are asked referential questions because of two reasons: Firstly, they did not want to reveal facts about their own life or their opinions in public as they didn't feel comfortable with such form of openness due to their shyness and lack of confidence. Secondly they feel their English is not good enough to express facts about their own life or their own opinions so they tend to remain silent. However among these students, a few students stated referential questions are still the most useful questions to be asked in class since they increase joy and variety in the lessons as different students share personal information and opinions. Some students said they learn about their friends' lives and ideas and this broadens their viewpoints. Some others added that by listening to their friends particularly those proficient in English, they can improve their speaking and vocabulary. It was also indicated referential questions lead to more sophisticated use 
of English in the lessons. As a result the students highlighted the communicative benefits of referential questions and emphasized that they promote in-class participation.

\section{Students' Views about the Effects of Referential Questions in Pre-writing Activities on Written Production}

The students overall found referential questions in pre-writing activities useful in generating written outcomes. Most students said referential questions increase their interests in the writing topic so they have the power of motivation. It was also emphasized they help them form ideas necessary for the writing to be produced so they are beneficial means for fruitful production. Besides, referential questions were thought to aid them create sample sentences to be used in their writing, thus they were deemed to act as a bridge between the pre-writing stage and the actual writing stage and prompt them to produce relatively accurate, meaningful and coherent outcomes. Additionally most students mentioned that it is very challenging to start a writing when they are alone, but when they are equipped with the right information and guidance in class and discuss the matter in pre-writing sessions navigated with teacher's referential questions, they tend to start their writings more easily and develop and conclude them more comfortably. They said when the teacher gets different responses through different referential questions in the class, this enriches their viewpoints and guides them about the main and supporting ideas that can be integrated in their writings. Thus according to the students' reports, the teacher's referential questions in the pre-writing lessons were reported to have a guiding role in writing and positively affect the production of written outcomes.

\section{Discussion, Conclusion and Recommendations}

The pre-writing lessons focusing on story and essay writing in this study displayed a variety of forms and functions with regard to referential questions. The forms of referential questions were found to be in the form of $5 \mathrm{Ws}$ and $1 \mathrm{H}$ (who, what, when, where, why and how) as well as yes-no questions, this-or-that questions and intonation questions. The questions served several functions classified as the i) productive, ii) communicative, iii) pedagogical, and iv) motivational functions. That is, referential questions i) prompted students to generate meaningful outputs related to the lesson content in both spoken and written form, ii) helped students to communicate about the topics and share ideas and creative outputs of their own, iii) guided the students about the content and outline of the relevant type of writing, and iv) led to a lively atmosphere marked with creative, productive and collaborative student involvement. The referential questions in pre-writing lessons asked within the contexts of story and essay writing, therefore, were observed to connect the given topic to the students' real and imaginative worlds and create a communicative setting with the potential to make the students linguistically and psychologically ready for writing production.

Additionally, as the findings revealed, the teacher and students agreed referential questions had substantial impacts on in-class participation and written production. According to the teacher reports, referential questions in pre-writing activities attracted the students' attention to the lessons, made possible that they actively, meaningfully and purposefully participated in the classroom interactions, 
created a positive and dynamic classroom atmosphere dominated by lifelike interactions, enhanced their motivation to speak, derived them to build concrete contents of their own with relatively complex structures and made them ready for writing. The teacher also reported she believed classroom interactions triggered with her referential questions effectively guided the students' written production as she found satisfactory answers to her $5 \mathrm{~W}$ and $1 \mathrm{H}$ questions asked in the pre-writing sessions in students' stories and sound replies to her opinion seeking questions in the essays. Furthermore, the teacher deemed referential questions and the interactions they created also affected the accurate use of relevant grammatical structures and vocabulary in the writings. Referential questions were also said to stimulate students' creative thinking as well as critical thinking skills and help them effectively build their writing content. Thus the teacher's use of referential questions in the pre-writing lessons were found to provide guidance for students' production of written outcomes.

The students also indicated referential questions promote in-class participation since they have the power to trigger them to express personal facts and ideas and thus participate more motivatedly in classroom interactions. Several students also mentioned their impacts on the complexity of their responses. Thus these questions were seen to create a sense of belonging among students as well as enthusiasm for communication in the classroom and give rise to sophisticated responses. On the other hand, some students were hesitant to answer such questions as they did not want to speak in public due to shyness and lack of confidence and/or deemed their English was not proficient enough to answer such questions. But they still believed in the benefits of these questions as they created a chance for them to observe and listen to a great variety of answers with varying forms and content. Lastly, the students also believed referential questions had positive impacts on the generation of written outcomes since they attracted their interest in the topic, energized ideas required in the writing to be produced, enriched their viewpoints with variety of opinions, created opportunities to practice the necessary forms and structures prior to writing and helped to build effective content and outlines via collaboration.

The findings of this study are in line with the forms and functions of referential questions investigated by Brock (1986), Long \& Sato (1983), Thompson (1991), Thornbury (1996), Kocer (2003) and Ozcan (2010). Besides, the present study displays a detailed portray of the forms and functions with refined categorizations, and some additions (i.e. this-or-that questions, intonation questions and pedagogical functions), and presents all these analyses within a pre-writing-specific framework. The findings of this study are also compatible with those where the participants believed in the effectiveness of referential questions in students' in-class participation (Farahiana \& Rezaee, 2012; Khadraoui, 2016; Ozcan, 2010), yet this study focusing on referential questions in pre-writing activities also highlights the fact that referential questions are likely to have an impact on students' generation of not only spoken but also written outcomes and provide them guidance about different types of writing and prompt them to create meaningful products with well-built outlines and accurate use of language. Moreover according to the current study not all the students were willing to answer referential questions due to lack of confidence, which is also a finding in Ozcan (2010). This study has also found that some students remained silent in response to referential questions as they believed they are not proficient enough to give effective 
replies. In addition, in this study referential questions were reported to generate complex use of language as indicated by the students and the teacher. This result is also compatible with the findings of research that referential questions are likely to lead to long and sophisticated responses (Bozorgian \& Fallah, 2017; Brock, 1986; Ernst, 1994; Lindenmeyer, 1990; Qashoa, 2012; Ozcan, 2010; Yilmaz, 2016; Zohrabi, YaghoubiNotash \& Khiabani, 2012). However, the present research also indicates if referential questions are included in pre-writing activities, they can affect the complexity of not only oral but also written outputs.

All in all, the study highlights the significance of using referential questions in pre-writing activities and implies they are likely to promote students' in-class participation and have them generate meaningful and purposeful spoken and written outcomes possibly constructed with complex forms of language. It is therefore necessary to train pre- and in-service teachers about the use of referential questions in pre-writing activities and encourage them to use such questions in class with different forms and functions. Another implication is that although referential questions can encourage production and communication in L2 among learners, some students may still remain silent and choose not to participate in in-class interactions due to their lack of confidence and low proficiency. However teachers can still encourage those learners and tell them to use all the linguistic and communicative potential they have to communicate their messages since it is through practice the students can improve in L2 production. Lastly, as the study implies, the teachers must also be aware of the fact that even if there may be students keeping silent in response to referential questions, they may still make use of the surrounding classroom interactions as such questions would create exposure to intense language production.

Further research on referential questions in pre-writing activities can be conducted in different educational contexts with larger groups. It is also recommended referential questions be investigated within other skills-based preparation processes such as in pre-reading and pre-listening activities. Since productivity is a major aim in EFL practices and writing is a complicated process challenging to start and complete, the pedagogical means likely to facilitate it must be efficiently employed in classroom settings. This study has shown that among these vehicles, referential questions that can be found in various forms in pre-writing activities can serve several productive, communicative, pedagogical and motivational purposes and positively influence students' in-class participation and production of written outcomes.

\section{References}

Brock, C. A. (1986). The effects of referential questions on ESL classroom discourse. TESOL Quarterly, 20, 77-59. https:/ / doi.org/10.2307/3586388

Brown, H. D. (2007). Teaching by principles: An interactive approach to language pedagogy. New York: Pearson Longman.

Bozorgian, H. and Fallah, S. (2017). EFL learner's speaking development: Asking referential questions. Malaysian Journal of Education, 42(2), 27-36. https:/ / doi.org/10.17576/JPEN-2017-42.02-03

Creswell, J. (2013). Qualitative inquiry and research design: Choosing among five approaches. Thousand Oaks, California: Sage. 
Eisterhold, J. (1990). Reading/writing connections: Toward a description for second language learners. In B. Kroll (Ed.), Second language writing: Research insights for the classroom (pp. 88-101). Cambridge: Cambridge University Press. https://doi.org/10.1017/CBO9781139524551.010

Ernst, G. (1994). "Talking circle”: Conversation and negotiation in the ESL classroom. TESOL Quarterly, 28, 293-322. https:// doi.org/10.2307/3587435

Farahian, M. and Rezaee, M. (2012). A case study of an EFL teacher's type of questions: An investigation into classroom interaction. Procedia - Social and Behavioral Sciences, 47, 161-167. https:// doi.org/10.1016/j.sbspro.2012.06.631

Grabe, W. and Kaplan, R. B. (1996). Theory and practice of writing: An applied linguistics perspective. Longman, New York.

Graham, S. and Perin, D. (2007). A meta-analysis of writing instruction for adolescent students. Journal of Educational Psychology, 99(3), 445-476. https:/ / doi.org/10.1037/0022-0663.99.3.445

Hairston, M. (1992). Diversity, ideology and teaching writing. College Composition and Communication, 43(2), 179-193. https://doi.org/10.2307/357563

Hyland, K. (2014). Second language writing (12 ${ }^{\text {th }}$ ed.). New York: Cambridge University Press.

Holmes, K. P. (2003). Show, don't tell: The importance of explicit prewriting instruction. Clearing House, 76(5), 241-243. https://doi.org/10.1080/00098650309602012

Johnson, A. P. (2008). Teaching reading and writing: a guidebook for tutoring and remediating students. Plymouth: Rowman and Littlefield Education.

Kennedy, G. E. (1983). The nature and quality of compensatory oral expression and its effects on writing in students of college composition. ERIC Document 240 597.

Khadraoui, H. (2016). Teachers' and students' attitudes towards the effect of referential questions on EFL classroom interaction (Unpublished MA thesis). Larbi Ben M'Hidi University, Oum El Bouaghi, Algeria.

Kocer, N. (2003). The communication strategies that elementary and advanced foreign language teachers use and their effects on students' participation in the lesson. (Unpublished MA thesis). Yildiz Technical University, Istanbul, Turkey.

Lally, C. G. (2000). First language influences in second language composition. The effect of pre-writing. Foreign Language Annals, (33)4, 428-432. https://doi.org/10.1111/j.1944-9720.2000.tb00623.x

Lay, N. D. S. (1982). Composing process of adult ESL learners: A case study. TESOL Quarterly, 16, 406.

Lindenmeyer, S. (1990). Study of referential and display questions and their responses in adult ESL reading classes (Unpublished doctoral dissertation). Portland State University, Portland, USA.

Long, M. H. and Sato, C. J. (1983). Classroom foreigner talk discourse: Forms and functions of teachers' questions. In H. W. Seliger and M. H. Long (Eds.), Classroom oriented research in second language acquisition (pp. 3-34). Rowley, MA: Newbury House. 
Matsuda, P. K. (2003). Process and post-process: A discursive history. Journal of Second Language Writing, 12, 65-83. https:/ / doi.org/10.1016/S10603743(02)00127-3

Meyer, G. D. (1980). Speaking as a pre-writing activity: Its application to teaching community college freshman composition pupils. ERIC Document 185585.

Morell, T. (2007). What enhances EFL students' participation in lecture discourse? Student, lecturer and discourse perspectives. Journal of English for Academic Purposes, 6, 222-237. https:/ / doi.org/10.1016/j.jeap.2007.07.002

Nunan, D. (1989). Designing tasks for the communicative classroom. Cambridge: Cambridge: Cambridge University Press.

Nunan, D. and Lamb, C. (1996). The self-directed teacher. Cambridge: Cambridge University Press.

Ozcan, S. (2010). The effects of asking referential questions on the participation and oral production of lower level language learners in reading classes (Unpublished MA thesis). Middle East Technical University, Ankara, Turkey.

Peregoy, S. F., and Boyle, O. F. (2017). Reading, writing, and learning in ESL: A resource book for K-12 teachers (7th edition). New York, NY: Pearson Education.

Qashoa, S. H. (2012). Effects of teacher question types and syntactic structures on EFL classroom interaction. The International Journal of Social Sciences, 7(1), 52-62.

Richards, Jack C. and Renandya, Willy A. (2002). Methodology in language teaching. Cambridge: Cambridge University Press. https://doi.org/10.1017/CBO9780511667190

Sert, O. and Seedhouse, P. (2011). Introduction: Conversation analysis in applied linguistics. Novitas Royal (Research on Youth and Language), 5(1), 1-14.

Seedhouse, P. (2011). Conversation analytic research into language teaching and learning. In E. Hinkel (Ed.), The handbook of research in second language teaching and learning, Volume II (pp. 345-363). London: Routledge.

Shi, L. (1998). Effects of prewriting discussions on adult ESL students' compositions. Journal of Second Language Writing, 7(3), 319-345. https://doi.org/10.1016/S1060-3743(98)90020-0

Shin, Y. (2008). The effects of planning on L2 writing: A study of Korean learners of English as a foreign language (Unpublished doctoral dissertation). The University of Iowa, Iowa, USA.

Sweigart. W. (1991). Classroom talk, knowledge development, and writing. Research in the Teaching of English. 25, 460-96.

Thompson, G. (1997). Training teachers to ask questions. ELT Journal, 51, 99-105. https:// doi.org/10.1093/elt/51.2.99

Tompkins, G.E. (2001). Literacy for the 21st century: A balanced approach. Columbus, $\mathrm{OH}$ : Merrill Prentice Hall.

Thornbury, S. (1996). Teachers research teacher talk. ELT Journal, 50, 279-289. https://doi.org/10.1093/elt/50.4.279

Walsh, S. and Li, L. (2013). Conversations as space for learning. International Journal of Applied Linguistics, 23(2), 247-266. https:// doi.org/10.1111/ijal.12005

Xianwei, P. (2009). Effects of prewriting discussion on the language quality of argumentative writings. Chinese Journal of Applied Linguistics, 32(5), 16-24. 
Yilmaz, S.D. (2016). The effect of syntactically different display and referential questions on students' responses in EFL classes. International Journal of Language Academy, 4(1), 315-330.

Zheng, S., and Dai, W. (2012). Studies and suggestions on prewriting activities. Higher Education Studies, 2(1), 79-87. https://doi.org/10.5539/hes.v2n1p79

Zohrabi, M., Yaghoubi-Notash, M. and Khiahani, S.Y. (2014). Teachers' use of display vs. referential questions across different proficiency levels. International Journal of Applied Linguistics and English Literature, 3(2), 96-100. https://doi.org/10.7575/aiac.ijalel.v.3n.2p.96

\section{Araştırmanın Etik Taahhüt Metni}

Yapılan bu çalışmada bilimsel, etik ve alıntı kurallarına uyulduğu; toplanan veriler üzerinde herhangi bir tahrifatın yapılmadığı, karşılaşılacak tüm etik ihlallerde "Cumhuriyet Uluslararası Eğitim Dergisi ve Editörünün" hiçbir sorumluluğunun olmadığı, tüm sorumluluğun Sorumlu Yazara ait olduğu ve bu çalışmanın herhangi başka bir akademik yayın ortamına değerlendirme için gönderilmemiş olduğu sorumlu yazar tarafından taahhüt edilmiştir.

\section{Author's Biodata / Yazar Bilgileri}

Elif KEMALOGLU ER Adana Alparslan Türkeş Bilim ve Teknoloji Üniversitesi İngilizce Mütercim ve Tercümanlık Bölümü'nde Doktor Öğretim Üyesi olarak çalışmaktadır. Doktora derecesini İngilizce Dili Eğitimi alanında Boğaziçi Üniversitesi'nden almıştır. Araştırma ilgi alanları arasında İngilizce dili öğretimi, ortak bir dil olarak İngilizce ve yabancı dil öğretim metodolojileri yer almaktadır.

Elif Kemaloglu Er works as an Assistant Professor at Adana Alparslan Türkeş Science and Technology University, Department of Translation and Interpreting. She received her $\mathrm{PhD}$ in English Language Education from Bogazici University. Her research interests include English language teaching, English as a lingua franca and foreign language teaching methodologies. 